\title{
Note on Translations
}

Unless otherwise noted, the translations are my own. When translating biblical passages I have modified the text in the King James Version of the English Bible to agree with the Latin translation (Vulgate) in use during the late-medieval period or with Martin Luther's translations into either Latin or German. Wherever possible primary material has been quoted from editions published in the sixteenth century rather than from modern editions. I have, for example, preferred to quote Augustine from the edition edited by Erasmus in $1528 / 1529$, although I have in each case compared the text with that of the Migne edition. The major exception is the work of Martin Luther, which I quote from the Weimar edition (unless noted otherwise) in order to avoid the confusion of the plethora of sixteenth-century editions of his individual and collected works. In order to shorten my still-lengthy notes, the original texts have been included in the notes only where the language itself is under investigation or where modern editions are not immediately accessible. 

"In His Image and Likeness" 
